\title{
Fever and leucocytosis accompanying asthmatic reactions due to occupational agents: frequency and associated factors
}

\author{
C. Lemière, D. Gautrin, C. Trudeau, H. Ghezzo, A. Desjardins, A. Cartier, J-L. Malo
}

Fever and leucocytosis accompanying asthmatic reactions due to occupational agents: frequency and associated factors. C. Lemière, D. Gautrin, C. Trudeau, H. Ghezzo, A. Desjardins, A. Cartier, J-L. Malo. @ CERS Journals Ltd 1996.

ABSTRACT: Fever is sometimes associated with asthmatic reactions following specific inhalation challenges with occupational agents. Our aims were to estimate the prevalence of fever in subjects with occupational asthma confirmed by specific inhalation challenge and to examine the characteristics and clinical correlates of subjects who develop fever on specific inhalation challenge.

We performed a retrospective analysis of 317 subjects who had positive specific inhalation challenge to occupational agents and a comparison of subjects who developed fever after specific inhalation challenge with a random sample of those who did not. Fifteen subjects (5\%) developed fever associated with positive specific inhalation challenge. They were compared with a random sample of 60 subjects who did not develop fever. The fever group: 1) showed a larger increase in absolute number of blood neutrophils, and a larger decrease both of blood lymphocytes and forced vital capacity after specific inhalation challenge; 2 ) included fewer atopics; 3 ) had been exposed more frequently to low rather than high molecular compounds; and 4) always experienced a late reaction and had more atypical reactions.

We conclude that after positive specific inhalation challenge; fever occurs infrequently, and is associated with an increase in blood neutrophils and a decrease in blood lymphocytes and forced vital capacity. Such reactions seem more likely to occur in nonatopic subjects exposed to low molecular weight agents.

Eur Respir J., 1996, 9, 517-523.
Dept of Chest Medicine, Hôpital du SacréCoeur, Montréal, Canada.

Correspondence: J-L. Malo

Dept of Chest Medicine

Sacré Coeur Hospital

5400 West Gouin

Montreal

Canada H4J 1C5

Keywords: Asthma

fever

leukocytosis

occupational diseases

Received: March 6 1995,

Accepted after revision November 201995

This work was partly funded by the Centre québécois d'excellence en santé respiratoire. J-LM is a research scholar with the Fonds de la recherche en santé du Québec and the Université de Montréal School of Medicine. C.L is the recipient of a research grant from L'Association Recherche et Partage (Paris, France).
Occupational asthma is currently the most common type of occupational lung disease [1]. Specific inhalation challenges consisting of replicating the subject's exposure in a controlled fashion in a hospital laboratory, are used in conjunction with other means to confirm the diagnosis [2]. During specific inhalation challenge, functional indices derived from forced expiratory manoeuvres are monitored to detect asthmatic reactions. As parenchymal or systemic reactions may occur in these challenges, other indices are also monitored such as oral temperature and white blood cell counts. Such systemic reactions, suggestive of hypersensitivity pneumonitis after exposure to occupational agents, have been reported with isocyanates [3] and metals [4]. However, the association of asthmatic and systemic reactions has been described more recently and only in isolated cases [5].

The frequency of fever and leucocytosis accompanying asthmatic reactions to occupational agents and the predictive factors are unknown. We hypothesized that such an association would be more common with nonimmediate reactions, that are usually non-immunoglobulin $\mathrm{E}$ ( $\mathrm{IgE}$ )-mediated and occur on exposure to low molecular weight chemicals. We therefore examined spirometry, oral temperature and white blood counts in 317 subjects who developed significant changes in forced expiratory volume in one second (FEV1) $(\geq 20 \%)$ after exposure to occupational agents to assess the frequency of accompanying systemic reactions and the predictive factors, if any.

Subjects and methods

\section{Subjects}

All subjects $(n=317)$ who had a positive specific inhalation challenge with occupational agents $(\geq 20 \%$ fall in FEV1) in our laboratory from 1981 onwards were included in this retrospective study. From these subjects, those who experienced fever $1 \mathrm{~h}$ or more after the end of specific inhalation challenge were selected. This group is referred to as the fever group. A control group, representative of the cohort, was selected in a randomized way from subjects who did not develop fever after specific inhalation challenge in order to make a satisfactory comparison with the fever group. The number of subjects allocated to the control group was four times the number included in the target group, as it was considered that this would increase the power of the analysis 
and make comparisons more satisfactory. The randomized group was comparable to the cohort concerning baseline data (see below in analysis of results).

As the occurrence of fever is associated with a nonimmediate pattern of asthmatic reaction (see below), another control group (one subject of the fever group for four subjects of the control group) was also randomized among the subjects who experienced a nonimmediate asthmatic reaction. It was also ensured that this second control group was comparable to the whole group for baseline data.

\section{Relevant data collection}

Demographic and clinical information (sex, age, smoking habits, medication, nature of occupational agent, duration of exposure before the onset of symptoms, duration of symptoms before removal from work) were collected, as well as spirometric values at the time of specific inhalation challenge. The atopic status was ascertained by skinprick testing with a battery of 16 common inhaled allergens. A subject was defined as atopic if he/she had at least one positive skin test, with a negative control.

For all subjects, spirometry (FEV1 and forced vital capacity (FVC)) had been monitored on a control day to ensure stability of asthma (changes in FEV $1 \leq 10 \%$ ). This control day was a nonexposure day in 21 subjects and a day of exposure to a control product (paint, lactose, resin, wood dust) in 54 subjects. Spirometry was performed according to proposed standards [6] on a Vitalograph (Vitalograph Ltd, Buckingham, UK) or Collins spirometer (W.E. Collins, Inc. Braintree, MA, USA). FEV1 was monitored at baseline, and then every $10 \mathrm{~min}$ for the first hour, every $30 \mathrm{~min}$ for $1 \mathrm{~h}$, and hourly for a total of at least $7 \mathrm{~h}$ after the end of the exposure. Bronchial responsiveness to methacholine was assessed at the end of the control day, using a Wright's nebulizer (output $=$ $0.14 \mathrm{~L} \cdot \mathrm{min}^{-1}$ ) at tidal volume breathing for $2 \mathrm{~min}$, according to the procedure outlined by COCKCROFT et al. [7].

A blood sample for white cell counts (total count, leucocytes, neutrophils, eosinophils and lymphocytes) was generally obtained on the morning and at the end of the control day. Only the white blood cell count obtained at the end of the control day was compared to the one obtained at the end of the challenge day. Therefore, the time of blood collection was similar on the control and challenge days.

On the days of exposure to the suspected offending agent, specific inhalation challenges were carried out in an $8 \mathrm{~m}^{3}$ challenge room, according to a proposed methodology [8], or using a closed circuit apparatus to generate isocyanates [9] or particles [10]. The duration of exposure was progressive (one breath, $15 \mathrm{~s}, 1 \mathrm{~min}, 2 \mathrm{~min}, 5$ min, etc.) either on the same day (high molecular weight agents) or different days (low molecular weight agents) for a maximum period of $2 \mathrm{~h}$ [2]. FEV1 was assessed immediately after each exposure period and at the same intervals as for the control day (see above). FVC and oral temperature were assessed before challenge and then hourly after the end of exposure. Bronchial responsiveness to methacholine was reassessed at the end of the last day or on the following day if FEV1 was not back to $\pm 10 \%$ of the value obtained on the day of the first methacholine testing. A blood sample was also obtained at the end of the day on which a significant fall in FEV1 occurred, or on the following day in a few cases.

\section{Analysis of results}

Reference values for spirometry were taken from KNUDSON et al. [11]. Values for provocative concentration of agonist causing a $20 \%$ fall in FEV $1\left(\mathrm{PC}_{20}\right)$ equal to or less than $16 \mathrm{mg} \cdot \mathrm{mL}^{-1}$ represented significant bronchial hyperresponsiveness [12]. Changes in $\mathrm{PC}_{20} \geq 3.2$ fold from one assessment to the next were considered to be significant [13]. A specific inhalation challenge was considered to be positive if subjects developed significant changes in FEV1 $(\geq 20 \%)$ after exposure to occupational agents.

Patterns of reaction were defined as follows. Classical or typical reactions: immediate, late, early late, dual, according to the definition of PePYs and HutchCroft [8]. Atypical reactions, according to PERRIN et al. [14]: 1) "progressive", progressive fall in FEV1, in the first minutes after or during exposure with a maximum fall reached 5-6 $\mathrm{h}$ after the end of exposure; 2) "square waved", immediate and maximum fall in FEV1 in the first minutes after exposure without significant recovery $(<10 \%$ fluctuation from the maximum fall) thereafter (up to $8 \mathrm{~h}$ ); 3 ) "prolonged immediate", similar to immediate but slower recovery (several hours). Fever was defined by an oral temperature above $37.2^{\circ} \mathrm{C}$ on at least two occasions during specific inhalation challenge. Indeed, Hendrick et al. [15] have demonstrated that a body temperature above $37.2^{\circ} \mathrm{C}$ was one of the six objective measurements showing a good sensitivity-specificity balance in subjects suffering from hypersensitivity pneumonitis.

The two randomized groups (four randomized subjects for one subject in the fever group) were first compared with the whole group, to ensure that it was a representative sample of the cohort, using several variables. Three statistical tests were used: 1) Chi-squared for dichotomous variables (i.e. sex, atopic status, smoking habits, medication, molecular weight of the occupational agent $\mathrm{PC}_{20}$ before and after specific inhalation challenge); 2) t-test for continuous variables (age, duration of exposure before symptoms, duration of symptoms before removal from work, FEV1, FVC, temperature); and 3) Mann-Witney test for biological variables that did not have a normal distribution according to Lilliefors test (leucocytosis, neutrophilia, lymphocytosis, eosinophilia).

The two control groups were not significantly different from the whole "negative" population. Therefore, the fever group could be compared with the control group representing the whole "negative" population and with the control group who experienced nonimmediate asthmatic reactions only. The same variables as listed above were examined. Variables were compared in the two groups according to criteria set for the previous analysis (see above). As the hypothesis had been made that the fever group had been exposed to low molecular weight agent more often (so the null hypothesis had not been set), a confidence interval test was used to compare the proportions of subjects exposed to low and high molecular weight agents in the two groups and to assess that the difference 
between these proportions was not null [16]. Significance was accepted at the 95\% level for all statistical tests. Statistical tests were carried out using Statistical Package for the Social Sciences (SPSS) (Chicago, IL, USA).

\section{Results}

\section{Characterization of the fever group and reactions}

Fifteen subjects of the 317 cases studied (5\%) experienced fever. Twelve of the 15 subjects who developed fever also had an increase of temperature after the specific inhalation challenge greater than one SD above the mean of changes in temperature. Figure 1 shows the distribution of temperatures for the whole cohort.

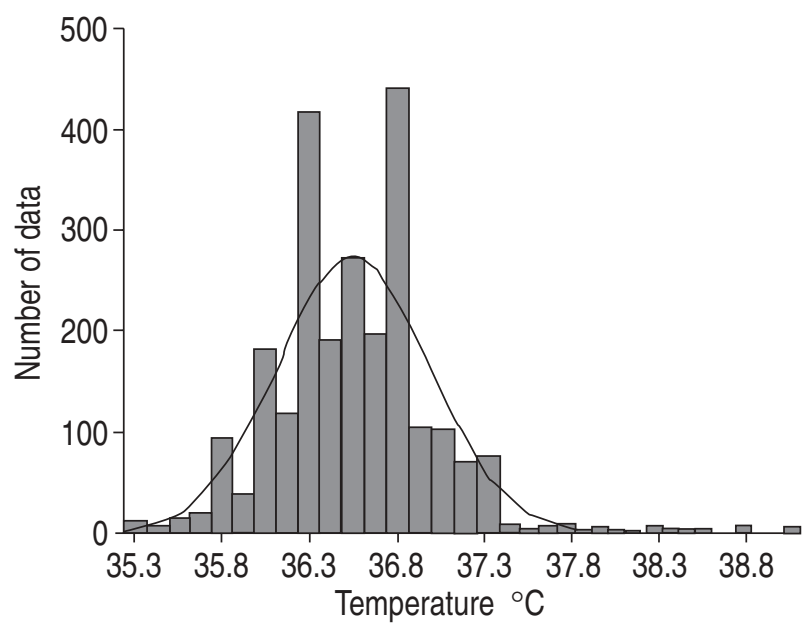

Fig. 1 - Distribution of temperature in the whole cohort. The normal distribution curve is illustrated.
The baseline anthropometric, clinical and functional results of the 15 subjects are listed in table 1 . Most subjects were males who had been exposed to low molecular weight agents and three, to high molecular weight agents. None of these subjects experienced isolated immediate reactions. Five subjects had isolated late reactions and three subjects had a dual reaction (immediate and late). Seven subjects demonstrated an atypical reaction of the progressive or of the square-waved pattern [14]. Six of the 15 subjects reported chills and malaise during specific inhalation challenge. Of these six, three had been exposed to isocyanates, two to metal fumes and one to polyester.

The changes in functional tests at the time of specific inhalation challenge are presented in table 2. Eleven subjects had a $\geq 15 \%$ fall in FVC. Blood was drawn before and after specific inhalation challenge in 11 of the 15 subjects. Nine out of 11 developed a significant increase in neutrophil count (increase in circulating neutrophils $\left(\geq 2.5 \times 10^{9}\right.$ cells $\cdot \mathrm{L}^{-1}\left(\geq 2,500\right.$ cells $\left.\left.\cdot \mathrm{mm}^{-3}\right)\right)$. Seven out of 11 showed a fall in lymphocyte number of $\left(0.5 \times 10^{9}\right.$ cells $\cdot \mathrm{L}^{-1}\left(500\right.$ cells $\left.\left.\cdot \mathrm{mm}^{-3}\right)\right)$ or more; with, for 6 of the 7 subjects, an absolute lymphopenia $\left(<1.5 \times 10^{9}\right.$ cells $\cdot \mathrm{L}^{-1}$ $\left(<1,500\right.$ cells $\left.\left.\cdot \mathrm{mm}^{-3}\right)\right)$. There were no significant changes in eosinophil count.

\section{Comparison between fever and nonfever groups (tables 3 and 4)}

Variables such as age, sex, smoking habits, medication, duration of exposure before symptoms, duration of symptoms before removal from work, and duration of exposure during the specific inhalation challenges were not different in the two groups (age and medication are

Table 1. - Anthropometric, clinical, functional and biological data of the fever group on the control day

\begin{tabular}{|c|c|c|c|c|c|c|c|c|c|c|c|c|c|c|c|}
\hline \multirow{2}{*}{$\begin{array}{l}\text { Sub. } \\
\text { No. }\end{array}$} & \multirow[b]{2}{*}{ Sex } & \multirow[b]{2}{*}{$\begin{array}{r}\text { Age } \\
\text { yrs }\end{array}$} & \multirow[b]{2}{*}{ Atopy } & \multirow[b]{2}{*}{$\begin{array}{l}\text { Smoking } \\
\text { habits }\end{array}$} & \multirow[b]{2}{*}{$\begin{array}{l}\text { Pattern of } \\
\text { reaction }\end{array}$} & \multirow[b]{2}{*}{$\begin{array}{l}\text { Occupational } \\
\text { agent }\end{array}$} & \multirow{2}{*}{\multicolumn{2}{|c|}{ FEV1 }} & \multirow{2}{*}{\multicolumn{2}{|c|}{ FVC }} & \multirow[b]{2}{*}{$\begin{array}{l}\mathrm{PC} 20 \\
\mathrm{mg} \cdot \mathrm{mL}^{-1}\end{array}$} & \multicolumn{3}{|c|}{$\begin{array}{c}\text { Blood cells } \\
\times 10^{9} \text { cells } \cdot \mathrm{L}^{-1}\end{array}$} & \multirow[b]{2}{*}{$\begin{array}{r}\mathrm{T} \\
{ }^{\circ} \mathrm{C} \\
\end{array}$} \\
\hline & & & & & & & & & & & & Leu & $\mathrm{Neu}$ & Lymph & \\
\hline 1 & M & 47 & + & ES & SW & MDI & 2 & 93 & 3.6 & 86 & 2.4 & 10.0 & 5.6 & 3.1 & 36.8 \\
\hline 2 & $\mathrm{~F}$ & 25 & - & NS & Dual & Psyllium* & 5 & 94 & 4.5 & 103 & 37 & 6.3 & 4.4 & 1.1 & 36.2 \\
\hline 3 & M & 37 & + & $\mathrm{S}$ & SW & Rabbit proteins* & 1 & 97 & 3.7 & 96 & 16 & 9.1 & 4.6 & 3.4 & 36.8 \\
\hline 4 & $\mathrm{~F}$ & 36 & - & $\mathrm{S}$ & EL & MDI & 5 & 107 & 4.0 & 104 & $>128$ & 13.5 & 9.9 & 3.1 & 36.2 \\
\hline 5 & M & 50 & - & $S$ & $\mathrm{P}$ & Polyester & & 109 & 4.9 & 118 & 0.65 & 6.1 & 2.6 & 2.7 & 36.3 \\
\hline 6 & M & 24 & - & NS & Late & Galvanized metal & & 45 & 3.8 & 66 & 0.9 & ND & ND & ND 3 & 36.9 \\
\hline 7 & M & 59 & - & ES & Late & Amine & 3.3 & 114 & 4.9 & 138 & 6.6 & 8.8 & 6.8 & 1.33 & 36.9 \\
\hline 8 & M & 29 & - & NS & Late & MDI & 4.0 & 103 & 4.5 & 96 & $>128$ & 9.3 & 4.6 & 4.0 & 36.8 \\
\hline 9 & M & 48 & - & $\mathrm{S}$ & SW & PPI & 3.0 & 82 & 4.3 & 95 & 13.5 & 5.7 & 3.2 & 1.9 & 36.7 \\
\hline 10 & M & 59 & - & $S$ & SW & Galvanized metal & 2.1 & 72 & 2.8 & 78 & 1.7 & 12.3 & 8.7 & 2.2 & 36 \\
\hline 11 & M & 58 & - & $S$ & Dual & Steel & 2.8 & 104 & 4.0 & 119 & 3.0 & 5.0 & 2.8 & 1.5 & 36.1 \\
\hline 12 & $\mathrm{~F}$ & 35 & - & ES & Late & Polypropylene & 2. & 76 & 3.2 & 77 & 0.3 & ND & ND & ND & 36.3 \\
\hline 13 & $\mathrm{M}$ & 34 & - & ES & $P$ & PPI & 3. & 88 & 4.3 & 88 & ND & ND & ND & ND & ND \\
\hline 14 & M & 35 & - & ES & SI & $\mathrm{HD}$ & 3. & 89 & 4.8 & 100 & 1.5 & 6.6 & 5.0 & 1.5 & 37.2 \\
\hline 15 & $\mathrm{~F}$ & 23 & + & NS & Dual & Cereals* & 3.4 & 119 & 3.8 & 118 & 0.5 & ND & ND & ND & 35.8 \\
\hline $\mathrm{Me}$ & & 40 & & & & & 3.2 & 93 & 4 & 99 & & 7.8 & 4.5 & 2.2 & 36.4 \\
\hline SD & & 13 & & & & & 0.5 & 19 & 0.6 & 19 & & 2.0 & 1.6 & 1.0 & 0.12 \\
\hline
\end{tabular}

Sub: subjects; M: male; F: female; FEV1: forced expiratory volume in one second; FVC: forced vital capacity; PC20: provocative concentration causing a $20 \%$ fall in FEV1; Leu: leucocytes; Neu: neutrophils; Lymph: lymphocytes; T: body temperature; S: smoker; NS: nonsmoker; ES: ex-smoker; MDI: diphenylmethane diisocyanate; HDI: hexamethylene diisocyanate; PPI: polymethylene polyphenylisocyanate; SW: square-waved; P: progressive; EL: early late; ND: not done; *: high molecular weight agent. 
Table 2. - Functional and biological data of the fever group following specific inhalation challenges

\begin{tabular}{|c|c|c|c|c|c|c|c|c|c|c|}
\hline \multirow{2}{*}{$\begin{array}{l}\mathrm{Pt} \\
\text { No. }\end{array}$} & \multirow[b]{2}{*}{$\begin{array}{l}\text { FEV1 } \\
\% \text { fall }\end{array}$} & \multirow[b]{2}{*}{$\begin{array}{c}\text { FVC } \\
\% \text { fall }\end{array}$} & \multirow[b]{2}{*}{$\begin{array}{c}\mathrm{PC}_{20} \\
\mathrm{mg} \cdot \mathrm{mL}^{-1}\end{array}$} & \multicolumn{6}{|c|}{ Blood cells $\times 10^{9}$ cells $\cdot \mathrm{L}^{-1}$} & \multirow[b]{2}{*}{$\begin{array}{c}\mathrm{T} \\
{ }^{\circ} \mathrm{C}\end{array}$} \\
\hline & & & & \multicolumn{2}{|c|}{ Leu } & \multicolumn{2}{|c|}{$\mathrm{Neu}$} & & ${ }^{p h}$ & \\
\hline 1 & 47 & 38 & ND & 19.8 & +9.8 & 17.0 & +11.4 & 1.4 & -1.7 & 38.4 \\
\hline 2 & 26 & 7 & 14 & 10.7 & +4.4 & 8.7 & +4.3 & 1.5 & +0.4 & 37.6 \\
\hline 3 & 29 & 16 & 16 & 17.6 & +8.5 & 15.4 & +10.8 & 1.1 & -2.3 & 38.0 \\
\hline 4 & 29 & 22 & $>128$ & 16.6 & +3.1 & 14.0 & +4.1 & 1.2 & -1.9 & 38.7 \\
\hline 5 & 41 & 30 & 0.4 & 16.7 & +10.6 & 14.7 & +12.1 & 1.2 & -1.5 & 39.0 \\
\hline 6 & 24 & 32 & 1.4 & 10.3 & - & 8.1 & - & 1.0 & - & 38.0 \\
\hline 7 & 21 & 15 & 6.6 & 8.0 & -0.8 & 6.0 & -0.8 & 1.1 & -0.2 & 37.6 \\
\hline 8 & 23 & 17 & $>128$ & 10.0 & +0.7 & 7.9 & +3.3 & 1.6 & -2.4 & 38.8 \\
\hline 9 & 17 & - & 1.3 & 10.7 & +5.0 & 8.6 & +5.4 & 1.1 & -0.8 & 38.1 \\
\hline 10 & 27 & 16 & 0.15 & 14.5 & +2.2 & 11.7 & +3.0 & 0.4 & -1.8 & 38.5 \\
\hline 11 & 36 & 32 & 2.7 & 9.8 & +4.8 & 7.8 & +5.0 & 1.6 & +0.1 & 38.5 \\
\hline 12 & 33 & 24 & 0.1 & 6.6 & - & 4.2 & - & 1.7 & - & 37.5 \\
\hline 13 & 48 & - & 0.7 & 6.6 & - & 4.4 & - & 1.7 & - & 37.4 \\
\hline 14 & 46 & 34 & 0.8 & 8.9 & +2.3 & 5.8 & +0.8 & 2.1 & +0.6 & 37.4 \\
\hline 15 & 28 & 14 & 1.2 & ND & - & ND & - & ND & - & 37.3 \\
\hline Mean & 31 & 23 & & 12.3 & +4.6 & 10 & +5.4 & 1.4 & -1.0 & 38.0 \\
\hline SD10 & 10 & & 4.3 & 3.7 & 4.3 & 4.3 & 0.5 & 1.1 & 0.15 & \\
\hline
\end{tabular}

For further abbreviations see legend to table 1.

Table 3. - Comparison of anthropometric, clinical and functional results in fever group and control non fever group

\begin{tabular}{|c|c|c|c|c|}
\hline Variables & & Fever group & Control group & P-value \\
\hline \multirow[t]{2}{*}{ Sex } & $\mathrm{M}$ & $11(73)$ & $46(77)$ & \\
\hline & $\mathrm{F}$ & $4(27)$ & $14(23)$ & $0.78 \dagger$ \\
\hline \multirow[t]{2}{*}{ Smoking } & + & $11(73)$ & $35(58)$ & \\
\hline & - & $4(27)$ & $25(42)$ & $0.28 \dagger$ \\
\hline \multirow[t]{2}{*}{ Atopy } & + & $3(20)$ & $38(63)$ & \\
\hline & - & $12(80)$ & $22(37)$ & $0.002 \dagger$ \\
\hline \multicolumn{5}{|l|}{ Molecular weight of agent } \\
\hline Low & & $12(80)$ & $35(58)$ & \\
\hline High & & $3(20)$ & $25(42)$ & $0.04 \ddagger$ \\
\hline \multicolumn{5}{|l|}{ Duration of exposure to agent } \\
\hline Duration of symptoms $\mathrm{yrs}^{*}$ & & $3.7 \pm 4.9$ & $3.4 \pm 3.9$ & $0.85^{\ddagger}$ \\
\hline \multicolumn{5}{|l|}{ Pattern of reaction to challenge } \\
\hline Isolated immediate & & 0 & $27(45)$ & $0.001 \dagger$ \\
\hline Nonimmediate & & $15(100)$ & $33(55)$ & \\
\hline Typical & & $8(53)$ & $53(88)$ & $0.001 \dagger$ \\
\hline Atypical & & $7(47)$ & $7(12)$ & \\
\hline $\mathrm{FEV}_{1} \mathrm{~L}^{*}$ & & $3.18 \pm 0.51$ & $3.36 \pm 0.78$ & $0.38 \div$ \\
\hline FVC $L^{*}$ & & $4.1 \pm 0.6$ & $4.4 \pm 1.0$ & $0.11^{\ddagger}$ \\
\hline$\%$ fall in $\mathrm{FEV}_{1}{ }^{*}$ & & $31 \pm 10$ & $30 \pm 12$ & $0.63 \ddagger$ \\
\hline$\%$ fall in $\mathrm{FVC}^{*}$ & & $\begin{array}{l}23 \pm 10 \\
(n=13)\end{array}$ & $\begin{array}{l}13 \pm 9 \\
(n=48)\end{array}$ & $0.001^{*}$ \\
\hline $\begin{array}{l}\text { Duration of exposure } \\
\text { during specific challenge } \mathrm{min}^{+} \\
\text {PC20 before SIC }\end{array}$ & & $15(3-120)$ & $31(0.08-4.80)$ & $0.53 \pi$ \\
\hline$<16 \mathrm{mg} \cdot \mathrm{mL}^{-1}$ & & $10(71)$ & $48(87)$ & \\
\hline$\geq 16 \mathrm{mg} \cdot \mathrm{mL}^{-1}$ & & $\begin{array}{l}4(29) \\
(n=14)\end{array}$ & $\begin{array}{c}7(13) \\
(\mathrm{n}=55)\end{array}$ & $0.15^{\dagger}$ \\
\hline \multicolumn{5}{|l|}{ PC20 after SIC } \\
\hline$<16 \mathrm{mg} \cdot \mathrm{mL}^{-1}$ & & $11(79)$ & $42(91)$ & \\
\hline$\geq 16 \mathrm{mg} \cdot \mathrm{mL}^{-1}$ & & $\begin{array}{l}3(21) \\
(\mathrm{n}=14)\end{array}$ & $\begin{array}{c}4(9) \\
(n=46)\end{array}$ & $0.19^{\dagger}$ \\
\hline
\end{tabular}

All data is pre specific inhalational challenges. Percentage values are given in parentheses. *: mean \pm SD. +: median (range). + : Chi-squared; \$: t-test or confidence interval test; I: Mann-Whitney test. $\mathrm{n}=15$ for the target group and $\mathrm{n}=60$ for the control group, otherwise stated in parenthesis. SIC: specific inhalation challenge. For further abbreviations see legend to table 1. 
Table 4. - Comparison of laboratory results in the fever and non fever control group

\begin{tabular}{|c|c|c|c|}
\hline Variables & $\begin{array}{l}\text { Fever } \\
\text { group }\end{array}$ & $\begin{array}{l}\text { Control } \\
\text { group }\end{array}$ & P-value \\
\hline \multicolumn{4}{|c|}{ Leucocytes $\times 10^{9}$ cells $\cdot \mathrm{L}^{-1}$} \\
\hline Before SIC & $\begin{array}{r}7.8 \pm 2.0 \\
(\mathrm{n}=11)\end{array}$ & $\begin{array}{r}7.2 \pm 2.0 \\
(n=52)\end{array}$ & 0.44 \\
\hline After SIC & $\begin{array}{r}11.7 \pm 5.3 \\
(\mathrm{n}=14)\end{array}$ & $\begin{array}{r}9.0 \pm 2.6 \\
(\mathrm{n}=44)\end{array}$ & 0.03 \\
\hline Difference & $\begin{array}{r}5.1 \pm 5.1 \\
(\mathrm{n}=11)\end{array}$ & $\begin{array}{r}1.7 \pm 2.4 \\
(\mathrm{n}=43)\end{array}$ & 0.0005 \\
\hline \multicolumn{4}{|c|}{ Neutrophils $\times 10^{9}$ cells $\cdot \mathrm{L}^{-1}$} \\
\hline Before SIC & $\begin{array}{r}4.5 \pm 1.6 \\
(\mathrm{n}=11)\end{array}$ & $\begin{array}{r}4.5 \pm 1.6 \\
(n=52)\end{array}$ & 0.94 \\
\hline After SIC & $\begin{array}{r}9.6 \pm 5.0 \\
(\mathrm{n}=14)\end{array}$ & $\begin{array}{r}6.1 \pm 2.6 \\
(n=44)\end{array}$ & 0.009 \\
\hline Difference & $\begin{array}{r}6.2 \pm 5.5 \\
(\mathrm{n}=11)\end{array}$ & $\begin{array}{r}1.5 \pm 2.5 \\
(\mathrm{n}=43)\end{array}$ & 0.0007 \\
\hline \multicolumn{4}{|c|}{ Lymphocytes $\times 10^{9}$ cells $\cdot \mathrm{L}^{-1}$} \\
\hline Before SIC & $\begin{array}{r}2.2 \pm 1.0 \\
(\mathrm{n}=11)\end{array}$ & $\begin{array}{r}1.9 \pm 0.8 \\
(\mathrm{n}=52)\end{array}$ & 0.51 \\
\hline After SIC & $\begin{array}{r}1.3 \pm 0.6 \\
(\mathrm{n}=14)\end{array}$ & $\begin{array}{r}2.0 \pm 0.9 \\
(\mathrm{n}=44)\end{array}$ & 0.01 \\
\hline Difference & $\begin{array}{r}-0.9 \pm 1.0 \\
(n=11)\end{array}$ & $\begin{array}{r}0.1 \pm 1.0 \\
(n=43)\end{array}$ & 0.008 \\
\hline \multicolumn{4}{|c|}{ Eosinophils $\times 10^{9}$ cells $\cdot \mathrm{L}^{-1}$} \\
\hline Before SIC & $\begin{array}{c}0.3 \pm 0.3 \\
(\mathrm{n}=9)\end{array}$ & $\begin{array}{r}0.3 \pm 0.3 \\
(\mathrm{n}=50)\end{array}$ & 0.52 \\
\hline After SIC & $\begin{array}{r}0.2 \pm 0.2 \\
(\mathrm{n}=12)\end{array}$ & $\begin{array}{r}0.3 \pm 0.3 \\
(\mathrm{n}=44)\end{array}$ & 0.06 \\
\hline Difference & $\begin{array}{c}-0.2 \pm 0.3 \\
(n=8)\end{array}$ & $\begin{array}{r}0.0 \pm 0.3 \\
(n=41)\end{array}$ & 0.055 \\
\hline
\end{tabular}

Value are presented as mean \pm SD. Mann-Whitney test was used for level of significance. Comparing values before and after SIC. SIC: specific inhalation challenge.

not listed in table 3). However, the proportion of atopic subjects was lower and exposure to low molecular weight agents was more frequent in the fever group. No subject from the fever group developed an isolated immediate reaction, whereas $45 \%$ of the control group did. Subjects in the fever group more often developed reactions of an atypical pattern. Analysis of changes in spirometry data revealed that the fever group had a more significant fall in FVC. The comparison of FEV1, maximum fall of FEV1 after specific inhalation challenge and bronchial responsiveness before and after specific inhalation challenge showed no differences between the two groups.

White blood cell count analysis showed a significant increase in leucocytosis after specific inhalation challenge with neutrophilia and lymphopenia in the fever group but no significant changes in eosinophils (table 4). There was also a significant increase in leucocyte and neutrophil counts after specific inhalation challenge in the control group, but this increase was significantly lower than the one observed in the fever group. We observed a decrease in lymphocyte count in the fever group but not among the control group before and after specific inhalation challenge. There were significant differences in leucocytosis, neutrophilia and lymphocytosis between the fever and control groups after specific inhalation challenge, whereas they had similar values at baseline.
Comparison between fever group and nonfever control subgroup with late reactions only (control LAR $n=60$ )

No significant differences were found between the two groups for the following variables: gender, mean age, smoking habits, medication, molecular weight of the offending agent, duration of exposure before symptoms and duration of symptoms, baseline FEV1 and FVC, maximum fall of FEV1 and FVC during the specific inhalation challenge. There were fewer atopic subjects in the fever group ( 3 out of $15 ; 20 \%$ ) than in the control LAR group $(60 \%)(\mathrm{p}=0.006)$. There was a higher proportion of subjects with hyperresponsivess to methacholine in the control LAR group than in the fever group before (97\% as compared with $71 \%$; $\mathrm{p}=0.01)$ and after ( $100 \%$ compared to $78 \%$; $\mathrm{p}=0.008$ ) specific inhalation challenge. The increase in leucocytosis was significantly higher in the fever group (from $7.8 \pm 2.0$ to $11.7 \pm 5 \times 10^{9}$ cells $\cdot \mathrm{L}^{-1}$ ) than in the control LAR group (from $7.2 \pm 1.7$ to $8.3 \pm 2.6 \times 10^{9}$ cells $\left.\cdot \mathrm{L}^{-1} ; \mathrm{p}<0.05\right)$. The increase in neutrophils in the fever group was also greater (from $4.5 \pm 1.6$ to $9.6 \pm 5.0 \times 10^{9}$ cells $\cdot \mathrm{L}^{-1}$ ) than in the control LAR group (from $4.5 \pm 1.6$ to $5.3 \pm 2.6 \times 10^{9}$ cells $\cdot \mathrm{L}^{-1 ;} \mathrm{p}<0.05$ ). There was a significant decrease in lymphocytosis in the fever group (from $2.2 \pm 1.0$ to $1.3 \pm 0.6 \times 10^{9}$ cells $\cdot \mathrm{L}^{-1}$ ) as compared to the control LAR group (from $1.9 \pm 0.8$ to $2.1 \pm 0.9 \times 10^{9}$ cells $\left.\cdot \mathrm{L}^{-1}\right) ; \mathrm{p}<0.05$. There was also a significant decrease in the number of eosinophils in the fever group (from $0.3 \pm 0.3$ to $0.1 \pm 0.2 \times 10^{9}$ cells $\left.\cdot \mathrm{L}^{-1}\right)$ as compared to the control LAR group (from $0.3 \pm 0.3$ to $0.4 \pm 0.2 \times 10^{9}$ cells $\cdot \mathrm{L}^{-1}$; $\mathrm{p}<0.05$ ).

\section{Discussion}

This retrospective study in 317 subjects with occupational asthma shows that $5 \%$ of them developed both asthmatic reaction and fever after exposure to the occupational agent that they reacted to. Subjects who developed fever had been exposed more often to low molecular weight agents and experienced late or atypical asthmatic reactions.

From a physiological point of view, it is difficult to set the frontier between an airway reaction and a parenchymal involvement after specific inhalation challenge. Parenchymal involvement is classically accompanied by systemic manifestations, such as fever and leucocytosis. Some airway involvement in hypersensitivity pneumonitis due to bird proteins has been described by HaRgREAVE and PePYs [17]. Among the 36 subjects who experienced a reaction on bronchoprovocation test with bird sera, $5(14 \%)$ showed late reactions consisting of fever and asthma according to Hargreave and PePYS [17]. VANDENPLAS et al. [3] described eight subjects who developed a hypersensitivity pneumonitis-type response after being exposed to diphenylmethane diisocyanate (MDI). These authors reported some degree of airway obstruction, but only one subject had evidence of bronchial hyperresponsiveness to methacholine.

Among the approximately 250 agents causing occupational asthma [18], only metal fumes [4] and isocyanates [19], had been, to our knowledge, identified as causing a mixed reaction, with evidence of asthma and parenchymal 
involvement principally manifested by fever and leucocytosis. MALO and co-workers [5] reported the case of a subject who developed both fever due to an alveolitis and asthma after exposure to hexamethylene diisocyanate (HDI). MALO and CARTIER [4] also described such a mixed reaction in two solderers who developed a late asthmatic reaction after exposure to fumes of galvanized metal. One of the two subjects also demonstrated a significant increase in oral temperature and peripheral neutrophils.

In the current study, evidence of a mixed bronchial and alveolar reaction was found. The proportion of subjects who had bronchial hyperresponsiveness to methacholine before specific inhalation challenge and the proportion of subjects who increased the level of their bronchial responsiveness to methacholine were similar to the results obtained by MALO and co-workers [20], who showed that 41 out of 101 subjects $(40 \%)$ demonstrated a change in $\mathrm{PC}_{20}$ after a late reaction on specific inhalation challenge. Moreover, the frequency of changes in $\mathrm{PC}_{20}$ was the same among the fever group and the control group that did not experience fever. Therefore, our subjects in the fever group, in all likelihood, experienced an alveolar reaction in addition to their asthmatic reaction. We found that subjects who experienced fever more often have normal responsiveness to methacholine pre- and post-specific inhalation challenges than subjects who experienced nonimmediate asthmatic reactions without fever.

In this study, evidence of a "hypersensitivity pneumonitis reaction" relied mainly on the identification of fever and leucocytosis. However, three of our six patients exposed to isocyanates and three other subjects exposed to other agents experienced the combination of an oral temperature $>37.2^{\circ} \mathrm{C}$, a fall in $\mathrm{FVC} \geq 15 \%$, a significant increase in absolute number of neutrophils $\left(\geq 2,500\right.$ cells $\left.\cdot \mathrm{mm}^{-3}\right)$, and a significant fall in the number of blood lymphocytes $\left(<500\right.$ cells $\left.\cdot \mathrm{mm}^{-3}\right)$ together with absolute lymphopenia after specific inhalation challenge. We did not perform other tests to document the "alveolar component" except in a few cases. Nevertheless, Hendrick et al. [15] have shown that a temperature above $37.2^{\circ} \mathrm{C}$, an increase in leucocyte count of $\geq 2,500$ cells $\cdot \mathrm{mm}^{-3}$, and a fall in FVC of $15 \%$ with absolute lymphopenia were sensitive indices of a positive alveolar response after specific inhalation challenge; chest radiograph and transfer factor were less sensitive indices. Comparison of our fever group with the control group showed significant differences in the fall in FVC, increase of neutrophils and decrease in lymphocytes, suggesting that these subjects experienced a hypersensitivity pneumonitis-type reaction. However, some of our subjects did not meet all the criteria set by HENDRICK [15].

In the current study, we examined the variables associated with the development of fever. Fever occurred more often in subjects exposed to low molecular weight agents: 12 of the 15 patients who experienced fever had been exposed to low molecular weight agents. If occupational asthma caused by the exposure to high molecular weight compounds is, in most cases, IgE-mediated, occupational asthma due to low molecular weight agents is not usually so [21]. The mechanism of action of low molecular weight agents on the airways and lung remains largely unknown. If some of these agents act through immunological mechanisms, other factors, such as the intrinsic chemical properties and pharmacological mechanisms, are probably involved [21,22]. Some of these properties might explain the induction of hypersensitivity pneumonitis or acute lung reaction. It is also interesting to note that none of the patients who experienced fever developed an isolated immediate reaction, whereas $45 \%$ of the control group's subjects did.

Our fever group included 15 subjects, 12 of whom had been exposed to low molecular weight agents, which are more likely to cause nonimmediate reactions. The development of fever in subjects exposed to high molecular weight agents is more difficult to explain as it is IgEmediated, whereas the mechanism of reactions due to low molecular weight agents is unknown for the majority of agents. Nevertheless, the three subjects who developed fever following exposure to high molecular weight agents also developed late or dual asthmatic reactions, which further suggests that the type of reaction and not the nature of the agent per se conditions the likelihood of developing fever. The association of asthmatic reactions and fever reported in the literature concerns subjects who developed a late type of reaction [17]. Subjects of the fever group more often experienced atypical nonimmediate reactions of the square-waved or progressive patterns [14]. The mechanism of these reactions is unknown. Fever was also more frequently observed among nonatopic patients. This cannot only be explained by the fact that subjects who experienced fever were more often exposed to a low molecular weight agent. Indeed, there was no significant difference in the molecular weight of the offending agent between the fever group and the control group of subjects with nonimmediate reactions and no fever.

In conclusion, fever was found to be associated with asthmatic reactions in $5 \%$ of subjects with positive challenges to occupational agents. Exposure to a low molecular weight agent and the occurrence of a late, especially atypical, pattern of reaction are, therefore, risk factors for the development of fever accompanying an asthmatic reaction. The pathogenesis of fever and leucocytosis accompanying these reactions remains to be explored.

Acknowledgements: The authors wish to express their gratitude to L. Schubert for reviewing this manuscript.

\section{References}

1. Bernstein IL, Chan-Yeung M, Malo JL, Berstein DI. Asthma in the workplace. New York, Marcel Dekker Inc., 1993.

2. Cartier A, Malo JL. Occupational challenge tests. In: Bernstein IL, Chan-Yeung M, Malo JL, Bernstein DI, eds. Asthma in the Workplace. New York, Marcel Dekker Inc., 1993, pp. 215-247.

3. Vandenplas O, Malo JL, Dugas M, et al. Hypersensitivity pneumonitis-like reaction among workers exposed to diphenylmethane diisocyanate (MDI). Am Rev Respir Dis 1993; 147: 338-346. 
4. Malo JL, Cartier A. Occupational asthma due to fumes of galvanized metal. Chest 1987; 92: 375-377.

5. Malo JL, Ouimet G, Cartier A, Levitz D, Zeiss R. Combined alveolitis and asthma due to hexamethylene diisocyanate (HDI), with demonstration of crossed respiratory and immunologic reactivities to diphenylmethane diisocyanate (MDI). J Allergy Clin Immunol 1983; 72: 413-419.

6. American Thoracic Society. Standardization of spirometry: 1987 update. Am Rev Respir Dis 1987; 136: 1285-1307.

7. Cockcroft DW, Killian DN, Mellon JJA, Hargreave FE. Bronchial reactivity to inhaled histamine: a method and clinical survey. Clinical Allergy 1977; 7: 235-243.

8. Pepys J, Hutchcroft BJ. Bronchial provocation tests in etiologic diagnosis and analysis of asthma. Am Rev Respir Dis 1975; 112: 829-859.

9. Vandenplas O, Malo JL, Cartier A, Perreault G, Cloutier Y. Closed-circuit methodology for inhalation challenge test with isocyanates. Am Rev Respir Dis 1992; 145: 582-587.

10. Cloutier Y, Lagier F, Cartier A, Malo JL. Validation of an exposure system to particles for the diagnosis of occupational asthma. Chest 1992; 102: 402-407.

11. Knudson RJ, Lebowitz MD, Holberg CJ, Burrows B. Changes in the normal maximal expiratory flow-volume curve with growth and aging. Am Rev Respir Dis 1983; 127: 725-734.

12. Malo JL, Pineau L, Cartier A, Martin RR. Reference values of the provocative concentrations of methacholine that cause $6 \%$ and $20 \%$ changes in forced expiratory volume in one second in a normal population. Am Rev Respir Dis 1983; 128: 8-11.

13. Dehaut P, Rachiele A, Martin RR, Malo JL. Histamine dose-response curves in asthma: reproducibility and sensitivity of different indices to assess response. Thorax 1983; 38: 516-522.
14. Perrin B, Cartier A, Ghezzo H, et al. Reassessment of the temporal patterns of bronchial obstruction after exposure to occupational sensitizing agents. J Allergy Clin Immunol 1991; 87: 630-639.

15. Hendrick DJ, Marshall R, Faux JA, Krall JM. Positive "alveolar" responses to antigen inhalation provocation tests: their validity and recognition. Thorax 1980; 35: 415-427.

16. Eberhardt KR, Fligner MA. A comparison of two tests for equality of two proportions. Am Stat 1977; 31: 151-155.

17. Hargreave FE, Pepys J. Allergic respiratory reactions in bird fanciers provoked by allergen inhalation provocation tests. J Allergy Clin Immunol 1972; 50: 157-173.

18. Chan-Yeung M, Malo JL. Compendium I. Table of the major inducers of occupational asthma. In: Bernstein IL, Chan-Yeung M, Malo JL, Bernstein DI, eds. Asthma in the workplace. New York, Marcel Dekker Inc., 1993: 595-623.

19. Zeiss CR, Kanellakes TM, Bellone JD, Levitz D, Pruzansky JJ, Patterson R. Immunoglobulin E-mediated asthma and hypersensitivity pneumonitis with precipitating antihapten antibodies due to diphenylmethane diisocyanate (MDI) exposure. J Allergy Clin Immunol 1980; 65: 346352.

20. Malo JL, Ghezzo H, L'Archevêque J, Cartier A. Late asthmatic reactions to occupational sensitizing agents: frequency of changes in nonspecific bronchial responsiveness and of response to inhaled beta ${ }_{2}$-adrenergic agent. J Allergy Clin Immunol 1990; 85: 834-842.

21. Mapp CE, Saetta M, Maestrelli P, et al. Mechanisms and pathology of occupational asthma. Eur Respir $J$ 1994; 7: 544-554.

22. Agius RM, Nee J, McGovern B, Robertson A. Structure activity hypothesis in occupational asthma caused by low molecular weight substances. Ann Occup Hyg 1991; 35: 129-137. 